\title{
Arsenic Exposure and Type 2 Diabetes: MicroRNAs as Mechanistic Links?
}

\author{
Rowan Beck $^{1,2}$ - Miroslav Styblo ${ }^{3}$ Praveen Sethupathy ${ }^{1,2}$
}

Published online: 8 March 2017

(C) The Author(s) 2017. This article is published with open access at Springerlink.com

\begin{abstract}
Purpose of Review The goal of this review is to delineate the following: (1) the primary means of inorganic arsenic (iAs) exposure for human populations, (2) the adverse public health outcomes associated with chronic iAs exposure, (3) the pathophysiological connection between arsenic and type 2 diabetes (T2D), and (4) the incipient evidence for microRNAs as candidate mechanistic links between iAs exposure and T2D. Recent Findings Exposure to iAs in animal models has been associated with the dysfunction of several different cell types and tissues, including liver and pancreatic islets. Many microRNAs that have been identified as responsive to iAs exposure under in vitro and/or in vivo conditions have also been shown in independent studies to regulate processes that underlie T2D etiology, such as glucose-stimulated insulin secretion from pancreatic beta cells.

Summary Defects in insulin secretion could be, in part, associated with aberrant microRNA expression and activity. Additional in vivo studies need to be performed with standardized concentrations and durations of arsenic exposure in order
\end{abstract}

This article is part of the Topical Collection on Diabetes Epidemiology

Miroslav Styblo and Praveen Sethupathy contributed equally to this work.

Praveen Sethupathy

praveen_sethupathy@med.unc.edu

1 Department of Genetics, School of Medicine, University of North Carolina at Chapel Hill, Chapel Hill, NC 27599, USA

2 Curriculum in Genetics and Molecular Biology, University of North Carolina at Chapel Hill, Chapel Hill, NC 27599, USA

3 Department of Nutrition, Gillings School of Global Public Health, University of North Carolina at Chapel Hill, Chapel Hill, NC 27599, USA to evaluate rigorously microRNAs as molecular drivers of iAs-associated diabetes.

Keywords Diabetes $\cdot$ Arsenic $\cdot$ MicroRNAs $\cdot \beta$-Cell $\cdot$ Insulin $\cdot$ Metabolism

\section{Introduction}

Type 2 diabetes (T2D) is a complex metabolic disorder characterized by hyperglycemia that is generally caused by defects in insulin production, secretion, and/or systemic action. While both genetics and lifestyle components, such as diet and exercise, can significantly increase risk for T2D, chronic exposure to chemical diabetogens is less studied in the context of T2D etiology. Inorganic arsenic (iAs) is one such environmental diabetogen. The Environmental Protection Agency (EPA) and the Agency for Toxic Substances and Disease Registry (ATSDR) rank arsenic as first on the US Priority List of Hazardous Substances. Over 300 million people across more than 70 countries are exposed to iAs in their drinking water, and chronic exposure to iAs is associated with numerous adverse health effects including cancer, cardiovascular disease, hypertension, and, notably, diabetes.

Though the exact mechanism by which arsenic influences metabolic disorders is unknown, dysregulation of microRNAs (miRNAs) has emerged as a potential mode of action. miRNAs are short, non-coding molecules that negatively regulate gene expression at the post-transcriptional level. They are involved in the control of metabolic processes associated with impaired glucose tolerance and diabetes, such as gluconeogenesis in the liver and insulin secretion from pancreatic beta cells. The identification of miRNAs as a potential mechanism for the development and progression of iAs-associated diabetes could open a new avenue for therapeutic options. 


\section{Sources of iAs Exposure}

Sources of human exposure to iAs are both natural and anthropogenic. Arsenic is a naturally occurring metalloid and is present mainly as a sulfide in over 200 mineral species containing a mixture of metals, including silver, lead, copper, nickel, antimony, cobalt, and iron $[1,2]$. Arsenic is released into air, water, and soil as a result of volcanic activity, leaching of arsenic from soil to groundwater, and industrial processes [1]. Approximately one-third of the global atmospheric flux of arsenic (7900 t/year) is estimated to be from natural sources with volcanic activity being the most significant contributor $[1,2]$. The rate of its release from minerals can be enhanced by mining activities, exposing the minerals to weathering processes during excavation and leading to the accumulation of iAs in soil and water. iAs is readily metabolized by microorganisms, plants, and animals into organoarsenic species, including volatile arsenicals that can enter the atmosphere [1,2].

Arsenic and arsenic-containing compounds have been produced and used commercially for centuries [3]. Major anthropogenic sources of arsenic are associated with mining, smelting of non-ferrous metals, and burning of fossil fuels, which lead to the contamination of air, water, and soil. Furthermore, the historical use of arsenic-containing pesticides and herbicides as well as the use of arsenic in the preservation of timber has left large tracts of agricultural land contaminated [1, 2]. Past and ongoing uses of arsenic include pharmaceuticals, wood preservatives, agricultural chemicals, and applications in the mining, metallurgical, glass-making, and semiconductor industries [3]. In most regions though, drinking water is the most common source of iAs for humans [4], followed by agricultural products contaminated with iAs or organorasenicals.

Once ingested, iAs is methylated to either trivalent iAs ${ }^{\mathrm{III}}$ or pentavalent $\mathrm{iAs}^{\mathrm{V}}$-containing metabolites, including methylarsenite (MAs ${ }^{\mathrm{III}}$ ), dimethylarsenite (DMAs ${ }^{\mathrm{III}}$ ), methylarsenate $\left(\mathrm{MAs}^{\mathrm{V}}\right)$, and dimethylarsenate (DMAs ${ }^{\mathrm{V}}$ ) [5-9]. A critical enzyme in this process is arsenic (+3 oxidation state) methyltransferase (AS3MT), a member of the large superfamily of $S$-adenosylmethionine (SAM)-dependent enzymes [10]. These reactions appear to occur irrespective of whether the means of exposure is inhalation, ingestion, or a parenteral route [3]. The methylated arsenic species are more readily excreted in the urine, resulting in lower tissue retention of iAs. Therefore, the methylation of iAs has been viewed historically as a detoxification process [11-13]. This notion, however, is being called into question, as there have been recent studies showing that the trivalent methylated species, $\mathrm{MAs}^{\mathrm{III}}$ and DMAs ${ }^{\mathrm{III}}$, are more toxic and biologically active than unmethylated iAs in laboratory models [14, 15]. In addition, growing evidence suggests that MAs ${ }^{\mathrm{III}}$ and DMAs ${ }^{\mathrm{III}}$ also contribute to the adverse health effects of chronic iAs exposure in humans $[16 \bullet \bullet, 17-19]$.

\section{Arsenic Exposure and Public Health}

The Environmental Protection Agency (EPA) and the Agency for Toxic Substances and Disease Registry (ATSDR) rank arsenic as first on the US Priority List of Hazardous Substances [20]. Both the inhalation and ingestion of iAs have been linked to an increased risk of cancer of the lungs, urinary bladder, kidney, skin, liver, and prostate [21]. Several studies have revealed an elevated cancer risk for populations exposed to varying amounts of iAs from industrial emissions [4, 21-23]. In addition, an association between various cancers and contaminated drinking water [21] has been observed in cohorts from a variety of regions around the world including Taiwan [24], Japan [25], USA [26], and parts of South America [27, 28]. Recent reports from the United Nations International Children's Emergency Fund (UNICEF) indicate that over 140 million people across more than 70 countries are exposed to iAs in their drinking water [29]. In the USA alone, there are over 13 million people drinking water containing iAs at levels higher than the current EPA maximum contaminant level of $10 \mu \mathrm{g} \mathrm{As} / \mathrm{L}$, i.e., ten parts per billion (ppb) [20]. While most dietary arsenic is derived from saltwater fish and seafood $[30,31]$, only a small proportion occurs in the inorganic form $[32,33]$. Significant amounts of iAs are absorbed when agricultural plants are grown in or watered with iAs-contaminated water, and so the most abundant sources of dietary iAs include rice, grains, and flour [34]. Chronic exposure to iAs has been associated with numerous adverse health effects in addition to cancer, including cardiovascular disease [35, 36], hypertension [37, 38], and recently, T2D [39].

Type 2 diabetes is a complex metabolic disorder characterized by hyperglycemia that is generally caused by defects in insulin production, secretion, and/or systemic action [19]. T2D can lead to numerous long-term complications such as cardiovascular disease, nerve and kidney damage, chronic inflammation, or diabetic ketoacidosis [19]. Risk factors for T2D include both genetic and environmental variables [40, 41]. Over 80 distinct genetic loci have now been identified across diverse human populations that significantly increase risk for T2D [42]. While lifestyle components such as diet and exercise are very important contributing factors, particularly given that obesity often precedes some forms of T2D, chronic exposures to environmental chemicals are less studied in the context of T2D etiology.

The first studies of an association between arsenic exposure and T2D took place in Europe in the mid-1990s and were focused on occupational exposure [43-45] to iAs, as well as in Taiwan and Bangladesh in the late 1980s to mid-1990s, which centered on iAs exposure through drinking water [46-48]. Findings in other studies were inconsistent [37, 49, 50], possibly due to variation in exposure measurements and lack of standardized diagnostic criteria, especially for populations with low-to-moderate iAs levels in drinking water 
( $<150 \mathrm{ppb})$. Therefore, the association with T2D was viewed as ambiguous at best. However, several of these studies assessed iAs exposure indirectly by measuring arsenic levels in drinking water sources rather than using biomarkers of exposure [46, 48]. Also, some of these studies ascertained diabetes status based on self-reporting or death certificates [43, 51]. More recent studies that use direct, quantitative methods to measure iAs exposure and that include specific clinically relevant criteria for diabetes, consistently find a significant association with diabetes at even low-to-moderate exposure levels [52-58]. For a thorough summary of these studies, we refer the reader to the following review articles [59••, 60, 61]. Notably, a review by the National Toxicology Program concluded that while further research is needed, recent studies of low-level exposure using improved measures of exposure and outcome support an association between arsenic and diabetes [59••]. With a growing appreciation for the epidemiological connection between iAs exposure and T2D, it is of substantial interest to determine whether, and the means by which, iAs contributes to T2D pathophysiology.

\section{Arsenic and T2D Pathophysiology}

Laboratory studies have shown that 48 -h exposure to $2 \mu \mathrm{M}$ of iAs ${ }^{\mathrm{III}}$, or $0.1 \mu \mathrm{M}$ of MAs ${ }^{\mathrm{III}}$ or DMAs ${ }^{\mathrm{III}}$, is sufficient to impair the in vitro function of pancreatic islets isolated from C57BL/ 6 mice as measured by glucose-stimulated insulin secretion (GSIS) [18]. In two other studies, $5 \mu \mathrm{M}$ of sodium arsenite (iAs ${ }^{\mathrm{III}}$ ) for $72 \mathrm{~h}$ in primary rat pancreatic $\beta$-cells reduced insulin mRNA expression [62] and $0.5 \mu \mathrm{M}$ sodium arsenite in a rat insulinoma cell line suppressed $\mathrm{Ca}^{2+}$ influx, thereby inhibiting insulin vesicle packaging and impairing GSIS [63]. In a separate report, a 96-h, 0.25- $\mathrm{MM}$ iAs ${ }^{\mathrm{III}}$ treatment of a rat insulinoma (INS-1-832/13) cell line was shown to induce a significant Nrf2-mediated antioxidant response, which suppresses endogenous reactive oxygen species that are thought to be involved in insulin secretion [64].

Aside from pancreatic $\beta$-cell defects, iAs ${ }^{\text {III }}$ exposure has been shown to inhibit differentiation of fat cells, or adipocytes, which play a major role in glucose utilization and energy homeostasis. Specifically, 3T3-L1 pre-adipocyte cells treated in vitro with $6 \mu \mathrm{M}$ iAs ${ }^{\text {III }}$ for 2 months decreased expression of PPAR $\gamma$ [65], which drives adipocytic differentiation [66]. Impaired PPAR $\gamma$ signaling in adipose can lead to reduced insulin sensitivity [65]. iAs ${ }^{\text {III }}$ and its trivalent methylated metabolites [17] were also shown to inhibit insulin signaling and insulin-stimulated glucose uptake in a mature mouse adipocyte (3T3-L1) cell line in culture [67, 68].

In the liver, $3 \mathrm{mg} / \mathrm{L}$ of sodium arsenite enhances gluconeogenesis in both normo-glycemic C57BLKS/J $(\mathrm{db} / \mathrm{m})$ and diabetic $\mathrm{C} 57 \mathrm{BKS} / \mathrm{Lepr}^{\mathrm{db}}(\mathrm{db} / \mathrm{db})$ mice, at least in part by increasing levels of protein tyrosine phosphatase-1B (Ptp1b) [69], which is a known suppressor of hepatic insulin signaling [70]. Another study in estrogen-deficient ICR/HaJ mice reported that $0.05 \mathrm{ppm}$ iAs in drinking water for 6 weeks can stimulate the transcription of phosphoenolpyruvate carboxykinase (Pepck) transcription and thereby likely promote hepatic glucose production [71].

Lastly, iAs is a potent endocrine disruptor of estrogen receptor (ER)-mediated gene regulation and has been shown to alter steroid hormone receptor (SR)-mediated signaling at very low, environmentally relevant concentrations in both cell culture and whole-animal models [72-74]. These receptors play a critical role in normal biology and development [75], including energy balance and glucose homeostasis [76]. Though the exact mechanisms of action remain unknown, multiple studies support an association between endocrine disruptors and metabolic syndrome [77, 78], which may partially explain how chronic exposure to iAs has been associated with pathophysiological illnesses such as T2D.

Taken together, these studies show that the epidemiological link between iAs exposure and T2D may be mediated in part by iAs-exposure-associated defects in several different cell types and tissues, including islets, adipose, and liver, leading to either impaired insulin secretion or insulin resistance. For more details on these studies, we refer the reader to the following reviews [59••, 79, 80]. The underlying molecular mechanisms of these defects remain poorly characterized and merit deeper investigation.

\section{Candidate Mechanisms Underlying Effects of Arsenic on Diabetes Pathways}

The precise mechanisms by which arsenic affects T2Drelevant pathways remain unclear. Several studies have observed reproducible changes in gene expression upon iAs exposure in lymphocytes (human), macrophages (human), and liver (mouse) [81-83]. The latter study in mouse liver also reported systematic changes in DNA methylation profiles upon iAs exposure. Recently, an association between levels of iAs exposure and DNA methylation patterns has been reported in studies of human populations as well [84-87]. For example, a study of iAs-exposed human populations in Bangladesh reported a positive association between global hypermethylation of peripheral blood leukocyte (PBL) DNA and $\mathrm{iAs}$ concentrations in urine and plasma in individuals with plasma folate concentrations $>9 \mathrm{nmol} / \mathrm{L}[87,88]$. These findings were supported by a study of a Mexican cohort, in which the promoters of 183 genes were differentially methylated in individuals exhibiting iAs-associated skin lesions; most of the affected genes have known links to cardiometabolic disorders [84].

Altered DNA methylation status can influence transcription of not only nearby protein-coding genes, but also non- 
coding RNAs (ncRNAs). In more recent years, one particular class of ncRNAs, microRNAs (miRNAs), has emerged both as responsive to iAs exposure and, independently, as candidate drivers of phenotypes in metabolic disorders such as T2D [86, 89-98]. Researchers in this field are just beginning to investigate whether miRNAs may serve as mechanistic links between arsenic exposure and diabetes. Given the heightened interest in miRNA-based diagnostic and therapeutic strategies [99-103], this area represents highly translational research that could yield findings of potential clinical utility.

\section{MicroRNAs: Potential Mechanistic Links}

miRNAs are short, non-coding RNA molecules about 22 nucleotides in length that are transcribed predominantly by RNA polymerase II and negatively regulate gene expression at the post-transcriptional level [104]. At present, more than 1000 miRNAs have been identified in the human genome. Over the last decade, it has become apparent that miRNAs play a crucial role in diverse biological processes predominantly through the fine-tuning of gene networks [105-107]. miRNAs reside either in protein coding genes where they are sometimes transcribed along with the host gene or can be found in non-protein coding regions with their own independent transcription units. Transcription leads to a primary miRNA transcript (pri-miRNA), which can range anywhere from a few hundred base pairs (bp) to hundreds of kilobases in length [108]. In the canonical miRNA biogenesis pathway, stretches of sequence in the pri-miRNA that form hairpinlike secondary structures are recognized and excised in the nucleus by the microprocessor complex involving DGCR8 and DROSHA. The resulting sequence, known as a precursor miRNA (pre-miRNA), is approximately 70-100 nucleotides in length and is exported from the nucleus into the cytoplasm by Exportin 5-Ran-GTP [104]. Once in the cytoplasm, Dicer cleaves the end of the pre-miRNA to produce a doublestranded RNA duplex about 22 base pairs in length. One or both of the strands is independently loaded onto the RNAinduced silencing complex (RISC), at which point the miRNA is ready to guide and tether the main effector protein in RISC, Argonaute (Ago), to target RNA sequences [104]. The stability of binding of the miRNA-RISC to a target depends in part on the extent of sequence complementarity between the miRNA and the target RNA. Once Ago is tethered to a target mRNA, it confers gene silencing by translational repression and/or mRNA degradation.

miRNAs can also be secreted into circulation and serve as plasma biomarkers $[109,110]$ of disease $[111,112]$. The stability of miRNAs in circulation arises from the fact that they are protected by microparticles, including exosomes and lipoproteins. Changes in the levels of circulating miRNAs can be predictive of disease onset and/or disease subtype/severity, which could lead to early diagnosis and improved treatment.

In recent years, researchers have studied changes in tissue miRNA expression in response to external stimuli, including environmental toxicants $[107,113,114 \bullet]$. Arsenic and other compounds have been associated with altered miRNA expression both ex vivo and in vitro [97, 107, 115]. For example, in the peripheral blood of steel workers, the levels of two miRNAs linked to tumor progression, miR-222 and miR-21, were associated with the level of exposure to a combination of arsenic, iron, lead, and other metals in particulate matter [116]. A recent literature review by Sollome et al. indicated that the levels of over 20 additional miRNAs have been reported as being altered by varying amounts of arsenic exposure in several different cell models [107]. These results suggest that arsenic and other co-occurring environmental toxins can work alone or cooperatively to modulate the expression of miRNAs.

miRNAs in a number of metabolic tissues, including liver, adipose, and islets, have been linked previously to the pathogenesis of diabetes [117•]. Several miRNAs have been implicated in the regulation of insulin signaling in the liver, adipose, and skeletal muscle, as well as insulin production and secretion in the pancreatic islets [118-124]. Five prominent examples from the literature are described below:

- In vivo studies in mice have revealed that miR-29 controls both lipogenic and insulin signaling pathways in the liver $[100,125]$. miR-29 has also been shown to respond to glucose and regulate insulin secretion in rodent $\beta$-celllike lines, potentially in part through regulation of monocarboxylate transporter 1 (Mct1) [126].

- Knockout and over-expression studies in mice showed that miR-7 regulates a molecular network that controls insulin granule exocytosis and pancreatic $\beta$-cell identity [127]. Moreover, miR-7 appears to play a role in $\beta$-cell adaptation during the development of diabetes.

- miR-24 was identified as a master regulator of $\beta$-cell proliferation and insulin secretion in vitro, in large part via its direct control of Hnfla and Neurod1 [128], encoded by two different genes in which specific mutations are known to cause maturity-onset diabetes of the young (MODY) [128].

- miR-375 was first shown to suppress GSIS in the MIN6 mouse $\beta$-cell-like cell line in part by targeting and repressing myotrophin (Mtpn) [119]. Subsequent studies revealed that miR-375 knockout mice exhibit altered pancreatic $\alpha$-cell to $\beta$-cell ratios, increased fasting and fed plasma glucagon levels, and increased gluconeogenesis and hepatic glucose output [120].

- In separate studies, miR-34a was shown in obese mice to drive metabolic dysfunction in both liver and adipose by suppressing the gene sirtuin 1 (Sirt1) and also by inhibiting fibroblast growth factor 19 and 21 (Fgf19 and Fgf21) signaling [101, 102, 129]. These reports suggested 


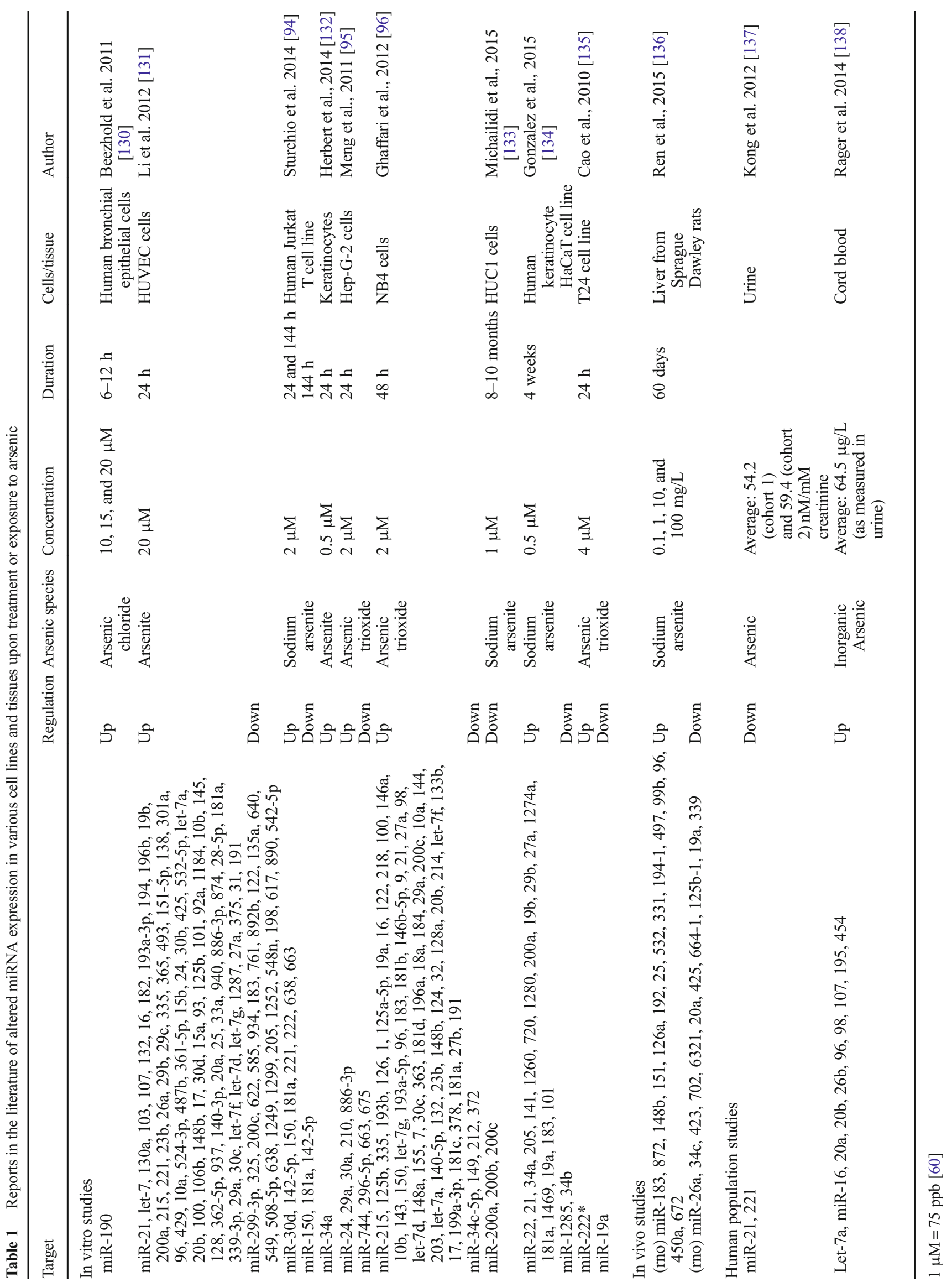


that miR-34a may be an attractive therapeutic target for obesity and related metabolic diseases.

Notably, most of these miRNAs have been identified as being responsive to arsenic in different tissues and cell lines (Table 1). For example, both miR-24 and miR-29 were shown to be significantly upregulated in human umbilical vein endothelial cells (HUVEC) after treatment with $20 \mu \mathrm{M}$ iAs for $24 \mathrm{~h}$ [107]. miR-29a was also altered in HepG2 hepatoma cells after treatment with $2 \mu \mathrm{M}$ arsenic trioxide $24 \mathrm{~h}$ [95]. Also, in another study, $0.5 \mu \mathrm{M}$ arsenite treatment of keratinocytes for $24 \mathrm{~h}$ led to an aberrant elevation of miR-34a [132].

While miRNAs are the drivers of several key metabolic processes associated with diabetes, such as insulin secretion and gluconeogenesis, no research has yet conclusively interconnected arsenic, miRNAs, and T2D. However, the overlap between the miRNAs modulated in expression by arsenic exposure and those involved with $\beta$-cell dysfunction and/or insulin signaling suggest that the effects of arsenic and its metabolites on the development of diabetes could be mechanistically explained, at least in part, by miRNAs and therefore warrants further investigation.

\section{Conclusions and Next Steps}

Data from recent studies support an association between iAs exposure and diabetes. While the underlying molecular mechanisms remain poorly characterized, miRNAs have emerged as one compelling class of molecules that may serve as a mechanistic link. Future studies must address several limitations and knowledge gaps, two of which we describe here.

(1) Functional studies of arsenic effects. Published in vitro and in vivo studies on arsenic exposure vary widely in terms of the arsenic species used, the concentration applied, the duration of treatment, and the cell types/tissues interrogated for functional assessment. In order to gain a more coherent understanding of the adverse diabetogenic effects of iAs, it will be important to identify and standardize a range of physiologically relevant concentrations and exposure durations. Furthermore, it will be critical to expand the cell types analyzed to include those of particular relevance to T2D etiology (e.g., intact islets, hepatocytes, intestinal epithelial cells, skeletal muscle cells). Finally, more in vivo studies, ideally across different strains of mice, are required in order to understand the effects of chronic iAs exposure in genetically diverse populations.

(2) MiRNA profiling in response to iAs. Most miRNA expression studies in response to iAs exposure/treatment have been carried out with real-time quantitative PCR (RT-qPCR) and/or microarray technology. The former is low-throughput and the latter suffers from several limitations, particularly in terms of distinguishing among functionally distinct miRNAs with very similar sequences. Although not without its own challenges, sequencing-based approaches have become the gold standard for miRNA profiling [139]. It will be imperative in the future to apply sequencing technology to study the miRNA response to iAs exposure/treatment.

Future studies should focus on identifying the miRNAs that are most reproducibly altered by iAs and determining through loss- and gain-of-function studies which if any of these miRNAs may mediate the adverse effects of iAs exposure. If specific miRNAs are identified as mechanistic links between iAs and metabolic defects, then they may represent attractive therapeutic targets for iAs-associated diabetes.

Acknowledgements We thank our colleagues Samir Kelada and John Buse for the helpful comments, as well as members of both the Sethupathy and Styblo laboratories for their feedback. Funding for this work is provided in part by the UNC Genetics \& Molecular Biology training grant from NIGMS awarded to R.B. (5T32GM007092), a Gillings Innovation Laboratory Award from the UNC School of Public Health awarded to M.S. and P.S., and the UNC Superfund grant from NIEHS (3P42ES005948-22S2).

\section{Compliance with Ethical Standards}

Conflict of Interest Rowan Beck, Miroslav Styblo, and Praveen Sethupathy declare that they have no conflict of interest.

Human and Animal Rights and Informed Consent This article does not contain any studies with human or animal subjects performed by any of the authors.

Open Access This article is distributed under the terms of the Creative Commons Attribution 4.0 International License (http:// creativecommons.org/licenses/by/4.0/), which permits unrestricted use, distribution, and reproduction in any medium, provided you give appropriate credit to the original author(s) and the source, provide a link to the Creative Commons license, and indicate if changes were made.

\section{References}

Papers of particular interest, published recently, have been highlighted as:

- Of importance

•- Of major importance

1. WHO. Air quality guidelines for Europe. Environ Sci Pollut Res. 2000;3(1):23. doi:10.1007/BF02986808.

2. Gomez-Caminero A, Howe P, Hughes M, Kenyon E, Lewis DR, Moore M, Ng JAA, GB. Environmental health criteria 224 arsenic and arsenic compounds (second edition). 2001;1-66.

3. ATSDR. ToxGuide for arsenic. CAS \# 7440-38-2. ToxGuide. 2007;1-2. www.atsdr.cdc.gov/toxpro2.html. 
4. International Agency for Cancer Research. IARC monographs on the evaluation of carcinogenic risks to humans. Some drinkingwater disinfectants and contaminants including arsenic. Int Agency Cancer Res Lyon. 2002;84:15-22.

5. Drobna Z, Xing W, Thomas DJ, Stýblo M. shRNA silencing of AS3MT expression minimizes arsenic methylation capacity of HepG2 cells. Chem Res Toxicol. 2006;19(7):894-8. doi:10. 1021/tx060076u.

6. Dheeman DS, Packianathan C, Pillai JK, Rosen BP. Pathway of human AS3MT arsenic methylation. Chem Res Toxicol. 2014;27(11):1979-89. doi:10.1021/tx500313k.

7. Drobna Z, Naranmandura H, Kubachka KM, et al. Disruption of the arsenic (+3 oxidation state) methyltransferase gene in the mouse alters the phenotype for methylation of arsenic and affects distribution and retention of orally administered arsenate. Chem Res Toxicol. 2009;22(10):1713-20. doi:10.1021/tx900179r.

8. Aposhian HV, Gurzau ES, Le XC, et al. Occurrence of monomethylarsonous acid in urine of humans exposed to inorganic arsenic. 2000.

9. Gong Z, Lu X, Ma M, Watt C, Le XC. Arsenic speciation analysis. Talanta. 2002;58(1):77-96. doi:10.1016/S0039-9140(02)002588 .

10. Styblo M, Del Razo LM, Vega L, et al. Comparative toxicity of trivalent and pentavalent inorganic and methylated arsenicals in rat and human cells. Arch Toxicol. 2000;74(6):289-99.

11. Marafante E, Vahter M, Envall J. The role of the methylation in the detoxication of arsenate in the rabbit. Chem Biol Interact. 1985;56(2-3):225-38.

12. Marafante E, Vahter M. Solubility, retention, and metabolism of intratracheally and orally administered inorganic arsenic compounds in the hamster. Environ Res. 1987;42(1):72-82.

13. Marafante E, Vahter M. The effect of methyltransferase inhibition on the metabolism of [74As]arsenite in mice and rabbits. Chem Biol Interact. 1984;50(1):49-57.

14. Petrick JS, Ayala-Fierro F, Cullen WR, Carter DE, Vasken AH. Monomethylarsonous acid (MMA(III)) is more toxic than arsenite in Chang human hepatocytes. Toxicol Appl Pharmacol. 2000;163(2):203-7. doi:10.1006/taap.1999.8872.

15. Petrick JS, Jagadish B, Mash EA, Aposhian HV. Monomethylarsonous acid (MMA(III)) and arsenite: $\mathrm{LD}(50)$ in hamsters and in vitro inhibition of pyruvate dehydrogenase. Chem Res Toxicol. 2001;14(6):651-6.

16.• Mendez MA, González-Horta C, Sánchez-Ramírez B, et al. Chronic exposure to arsenic and markers of cardiometabolic risk: a cross-sectional study in Chihuahua, Mexico. Environ Health Perspect. 2016;124(1):104-11. doi:10.1289/ehp.1408742. This study provides a thorough evaluation of the association of arsenic exposure at moderate doses $(25.5-<47.9 \mu \mathrm{g} / \mathrm{L})$ with markers of diabetes, triglyceridemia, and cholesterolemia in a population with a minimum 5-year uninterrupted period of exposure.

17. Walton FS, Harmon AW, Paul DS, Drobná Z, Patel YM, Styblo M. Inhibition of insulin-dependent glucose uptake by trivalent arsenicals: possible mechanism of arsenic-induced diabetes. Toxicol Appl Pharmacol. 2004;198(3):424-33. doi:10.1016/j. taap.2003.10.026.

18. Douillet C, Currier J, Saunders J, Bodnar WM, Matoušek T, Stýblo M. Methylated trivalent arsenicals are potent inhibitors of glucose stimulated insulin secretion by murine pancreatic islets. Toxicol Appl Pharmacol. 2013;267(1):11-5. doi:10.1016/j.taap. 2012.12.007.

19. Paul DS, Harmon AW, Devesa V, Thomas DJ, Stýblo M. Molecular mechanisms of the diabetogenic effects of arsenic inhibition of insulin signaling by arsenite and methylarsonous acid. Environ Health Perspect. 2007;115(5):734-42. doi:10.1289/ehp. 9867.
20. Agency for Toxic Substances DR. Toxicological profile for arsenic. U.S. Department of Health and Human Services. http://www. atsdr.cdc.gov/toxprofiles/tp.asp?id=22\&tid=3. Published 2007.

21. IARC Working Group on the Evaluation of Carcinogenic Risks to Humans. Some drinking-water disinfectants and contaminants, including arsenic. IARC Monogr Eval Carcinog Risks Hum. 2004;84:1-477.

22. Abernathy C. Exposure and health effects. Arsen Drink Water. 2001;100.

23. Lubin JH, Pottern LM, Stone BJ, Fraumeni JF. Respiratory cancer in a cohort of copper smelter workers: results from more than 50 years of follow-up. Am J Epidemiol. 2000;151(6):554-65.

24. Chen CJ, Kuo T-L, Wu MM. Arsenic and cancers. Lancet. 1988;331(8582):414-5. doi:10.1016/S0140-6736(88)91207-X.

25. Tsuda T, Babazono A, Yamamoto E, et al. Ingested arsenic and internal cancer: a historical cohort study followed for 33 years. Am J Epidemiol. 1995;141(3):198-209.

26. Bates MN, Smith AH, Cantor KP. Case-control study of bladder cancer and arsenic in drinking water. Am J Epidemiol. 1995;141(6):523-30.

27. Hopenhayn-Rich C, Biggs ML, Smith AH. Lung and kidney cancer mortality associated with arsenic in drinking water in Córdoba. Argent Int J Epidemiol. 1998;27(4):561-9.

28. Rivara MI, Cebrián M, Corey G, Hernández M, Romieu I. Cancer risk in an arsenic-contaminated area of Chile. Toxicol Ind Health. 1997;13(2-3):321-38.

29. Murcott S. Arsenic contamination in the world: an international sourcebook. London: IWA Publishing; 2012.

30. Wang H-S, Sthiannopkao S, Chen Z-J, et al. Arsenic concentration in rice, fish, meat and vegetables in Cambodia: a preliminary risk assessment. Environ Geochem Health. 2013;35(6):745-55. doi: 10.1007/s10653-013-9532-0.

31. Dabeka RW, McKenzie AD, Lacroix GM, et al. Survey of arsenic in total diet food composites and estimation of the dietary intake of arsenic by Canadian adults and children. J AOAC Int. 1993;76(1): $14-25$.

32. Li W, Wei C, Zhang C, Van Hulle M, Cornelis R, Zhang X. A survey of arsenic species in Chinese seafood. Food Chem Toxicol. 2003;41(8):1103-10. doi:10.1016/S0278-6915(03)00063-2.

33. Schaeffer R, Soeroes C, Ipolyi I, Fodor P, Thomaidis NS. Determination of arsenic species in seafood samples from the Aegean Sea by liquid chromatography-(photo-oxidation)-hydride generation-atomic fluorescence spectrometry. Anal Chim Acta. 2005;547(1):109-18. doi:10.1016/j.aca.2005.01.032.

34. Schoof R, Yost L, Eickhoff J, et al. A market basket survey of inorganic arsenic in food. Food Chem Toxicol. 1999;37(8):839 46. doi:10.1016/S0278-6915(99)00073-3.

35. Tseng CH, Chong CK, Chen CJ, Tai TY. Dose-response relationship between peripheral vascular disease and ingested inorganic arsenic among residents in blackfoot disease endemic villages in Taiwan. Atherosclerosis. 1996;120(1-2):125-33.

36. Chiou H-Y, Huang W-I, Su C-L, Chang S-F, Hsu Y-H, Chen C-J. Dose-response relationship between prevalence of cerebrovascular disease and ingested inorganic arsenic. Stroke. 1997;28(9).

37. Chen CJ, Hsueh YM, Lai MS, et al. Increased prevalence of hypertension and long-term arsenic exposure. Hypertens (Dallas, Tex 1979). 1995;25(1):53-60.

38. Rahman M, Tondel M, Ahmad SA, Chowdhury IA, Faruquee $\mathrm{MH}$, Axelson O. Hypertension and arsenic exposure in Bangladesh. Hypertens (Dallas, Tex 1979). 1999;33(1):74-8.

39. Tseng C-H. Metabolism of inorganic arsenic and non-cancerous health hazards associated with chronic exposure in humans. J Environ Biol. 2007;28(2 Suppl):349-57.

40. Murea M, Ma L, Freedman BI. Genetic and environmental factors associated with type 2 diabetes and diabetic vascular 
complications. Rev Diabet Stud. 2012;9(1):6-22. doi:10.1900/ RDS.2012.9.6.

41. Romao I, Roth J. Genetic and environmental interactions in obesity and type 2 diabetes. J Am Diet Assoc. 2008;108(4):S24-8. doi:10.1016/j.jada.2008.01.022.

42. Fuchsberger C, Flannick J, Teslovich TM, et al. The genetic architecture of type 2 diabetes. Nature. 2016;536(7614):41-7. doi: 10.1038 /nature18642.

43. Rahman M, Wingren G, Axelson O. Diabetes mellitus among Swedish art glass workers - an effect of arsenic exposure? Scand J Work Environ Health. 1996;22(2):146-9.

44. Jensen GE, Hansen ML. Occupational arsenic exposure and glycosylated haemoglobin. Analyst. 1998;123(1):77-80.

45. Rahman M, Axelson O. Diabetes mellitus and arsenic exposure: a second look at case-control data from a Swedish copper smelter. Occup Environ Med. 1995;52(11):773-4.

46. Lai MS, Hsueh YM, Chen CJ, et al. Ingested inorganic arsenic and prevalence of diabetes mellitus. Am J Epidemiol. 1994;139(5): 484-92.

47. Rahman M, Tondel M, Ahmad SA, Axelson O. Diabetes mellitus associated with arsenic exposure in Bangladesh. Am J Epidemiol. 1998;148(2):198-203. doi:10.1093/oxfordjournals.aje.a009624.

48. Tseng CH, Tai TY, Chong CK, et al. Long-term arsenic exposure and incidence of non-insulin-dependent diabetes mellitus: a cohort study in arseniasis-hyperendemic villages in Taiwan. Environ Health Perspect. 2000;108(9):847-51. doi:10.2307/3434992.

49. Tseng C-H, Tseng C-P, Chiou H-Y, Hsueh Y-M, Chong C-K, Chen C-J. Epidemiologic evidence of diabetogenic effect of arsenic. Toxicol Lett. 2002;133(1):69-76. doi:10.1016/S03784274(02)00085-1.

50. Longnecker MP, Daniels JL. Environmental contaminants as etiologic factors for diabetes. Environ Health Perspect. 2001; (Suppl 6):871-876. http://www.ncbi.nlm.nih.gov/pubmed/11744505. Accessed September 25, 2016.

51. Lewis DR, Southwick JW, Ouellet-Hellstrom R, Rench J, Calderon RL. Drinking water arsenic in Utah: a cohort mortality study. Environ Health Perspect. 1999;107(5):359-65.

52. Del Razo LM, García-Vargas GG, Valenzuela OL, et al. Exposure to arsenic in drinking water is associated with increased prevalence of diabetes: a cross-sectional study in the Zimapán and Lagunera regions in Mexico. Environ Health. 2011;10(1):73. doi:10.1186/1476-069X-10-73.

53. Coronado-González JA, Del Razo LM, García-Vargas G, Sanmiguel-Salazar F, Escobedo-de la Peña J. Inorganic arsenic exposure and type 2 diabetes mellitus in Mexico. Environ Res. 2007;104(3):383-9. doi:10.1016/j.envres.2007.03.004.

54. Navas-Acien A, Umans JG, Howard BV, et al. Urine arsenic concentrations and species excretion patterns in American Indian communities over a 10-year period: the strong heart study. Environ Health Perspect. 2009;117(9):1428-33. doi:10.1289/ ehp.0800509.

55. Navas-Acien A, Silbergeld EK, Pastor-Barriuso R, et al. Arsenic exposure and prevalence of type 2 diabetes in US adults. JAMA. 2008;300(7):814. doi:10.1001/jama.300.7.814.

56. Bräuner EV, Nordsborg RB, Andersen ZJ, Tjønneland A, Loft S, Raaschou-Nielsen O. Long-term exposure to low-level arsenic in drinking water and diabetes incidence: a prospective study of the diet, cancer and health cohort. Environ Health Perspect. 2014;122(10):1059-65. doi:10.1289/ehp.1408198.

57. James KA, Marshall JA, Hokanson JE, Meliker JR, Zerbe GO, Byers TE. A case-cohort study examining lifetime exposure to inorganic arsenic in drinking water and diabetes mellitus. Environ Res. 2013;123:33-8. doi:10.1016/j.envres.2013.02.005.

58. Kuo C-C, Howard BV, Umans JG, et al. Arsenic exposure, arsenic metabolism, and incident diabetes in the strong heart study. Diabetes Care. 2015;38(4):620-7. doi:10.2337/dc14-1641.
59.• Maull EA, Ahsan H, Edwards J, et al. Evaluation of the association between arsenic and diabetes: a National Toxicology Program workshop review. Environ Health Perspect. 2012;120(12):1658 70. doi:10.1289/ehp.1104579. This article provides a detailed evaluation of a multitude of studies on the association of arsenic and diabetes.

60. Navas-Acien A, Silbergeld EK, Streeter RA, Clark JM, Burke TA, Guallar E. Arsenic exposure and type 2 diabetes: a systematic review of the experimental and epidemiologic evidence. Environ Health Perspect. 2005;114(5):641-8. doi:10.1289/ehp.8551.

61. Tseng C-H, Tseng C-P, Chiou H-Y, Hsueh Y-M, Chong C-K, Chen C-J. Epidemiologic evidence of diabetogenic effect of arsenic. 2002;133. doi:10.1016/S0378-4274(02)00085-1.

62. Diaz-Villasenor A, Sanchez-Soto MC, Cebrián ME, OstroskyWegman P, Hiriart M. Sodium arsenite impairs insulin secretion and transcription in pancreatic $\beta$-cells. Toxicol Appl Pharmacol. 2006;214(1):30-4. doi:10.1016/j.taap.2005.11.015.

63. Díaz-Villaseñor A, Burns AL, Salazar AM, et al. Arsenite reduces insulin secretion in rat pancreatic $\beta$-cells by decreasing the calcium-dependent calpain-10 proteolysis of SNAP-25. Toxicol Appl Pharmacol. 2008;231(3):291-9. doi:10.1016/j.taap.2008. 05.018 .

64. Fu J, Woods CG, Yehuda-Shnaidman E, et al. Low-level arsenic impairs glucose-stimulated insulin secretion in pancreatic beta cells: involvement of cellular adaptive response to oxidative stress. Environ Health Perspect. 2010;118(6):864-70. doi:10.1289/ehp. 0901608.

65. Wauson EM, Langan AS, Vorce RL. Sodium arsenite inhibits and reverses expression of adipogenic and fat cell-specific genes during in vitro adipogenesis. Toxicol Sci. 2002;65(2):211-9. doi:10. 1093/toxsci/65.2.211.

66. Tontonoz P, Graves RA, Budavari AI, et al. Adipocyte-specific transcription factor ARF6 is a heterodimeric complex of two nuclear hormone receptors, PPAR7 and RXRa. Nucleic Acids Res. 1994;22(25):5628-34. doi:10.1093/nar/22.25.5628.

67. Divya SP, Pratheeshkumar P, Son YO, et al. Adipocytes and myotubes via oxidative stress-regulated mitochondrial sirt3FOXO3a signaling pathway. Toxicol Sci. 2015;146(2):290-300. doi:10.1093/toxsci/kfv089.

68. Xue P, Hou Y, Zhang Q, et al. Prolonged inorganic arsenite exposure suppresses insulin-stimulated AKT S473 phosphorylation and glucose uptake in 3T3-L1 adipocytes: involvement of the adaptive antioxidant response. Biochem Biophys Res Commun. 2011;407(2):360-5. doi:10.1016/j.bbrc.2011.03.024.

69. Liu S, Guo X, Wu B, Yu H, Zhang X, Li M. Arsenic induces diabetic effects through beta-cell dysfunction and increased gluconeogenesis in mice. Sci Rep. 2014;4:6894. doi:10.1038/ srep06894.

70. González-Rodríguez A, Mas Gutierrez JA, Sanz-González S, Ros M, Burks DJ, Valverde AM. Inhibition of PTP1B restores IRS1mediated hepatic insulin signaling in IRS2-deficient mice. Diabetes. 2010;59(3):588-99. doi:10.2337/db09-0796.

71. Huang C-F, Yang C-Y, Chan D-C, et al. Arsenic exposure and glucose intolerance/insulin resistance in estrogen-deficient female mice. Environ Health Perspect. 2015;123(11). doi:10.1289/ehp. 1408663

72. Bodwell JE, Gosse JA, Nomikos AP, Hamilton JW. Arsenic disruption of steroid receptor gene activation: complex dose-response effects are shared by several steroid receptors. Chem Res Toxicol. 2006;19(12):1619-29. doi:10.1021/tx060122q.

73. Kaltreider RC, Davis AM, Lariviere JP, Hamilton JW. Arsenic alters the function of the glucocorticoid receptor as a transcription factor. Environ Health Perspect. 2001;109(3):245-51.

74. Davey JC, Bodwell JE, Gosse JA, Hamilton JW. Arsenic as an endocrine disruptor: effects of arsenic on estrogen receptor- 
mediated gene expression in vivo and in cell culture. Toxicol Sci. 2007;98(1):75-86. doi:10.1093/toxsci/kfm013.

75. Bondesson M, Hao R, Lin C-Y, Williams C, Gustafsson J-Å. Estrogen receptor signaling during vertebrate development. Biochim Biophys Acta. 2015;1849(2):142-51. doi:10.1016/j. bbagrm.2014.06.005.

76. Ropero AB, Alonso-Magdalena P, Quesada I, Nadal A. The role of estrogen receptors in the control of energy and glucose homeostasis. Steroids. 2008;73(9):874-9. doi:10.1016/j.steroids.2007. 12.018 .

77. Wang W, Xie Z, Lin Y, Zhang D. Association of inorganic arsenic exposure with type 2 diabetes mellitus: a meta-analysis. J Epidemiol Community Health. 2014;68(2):176-84. doi:10.1136/ jech-2013-203114.

78. Song Y, Chou EL, Baecker A, et al. Endocrine-disrupting chemicals, risk of type 2 diabetes, and diabetes-related metabolic traits: a systematic review and meta-analysis. J Diabetes. 2016;8(4):516-32. doi:10.1111/1753-0407.12325.

79. Tseng C-H. The potential biological mechanisms of arsenicinduced diabetes mellitus. Toxicol Appl Pharmacol. 2004;197(2):67-83. doi:10.1016/j.taap.2004.02.009.

80. Paul DS, Hernández-Zavala A, Walton FS, et al. Examination of the effects of arsenic on glucose homeostasis in cell culture and animal studies: development of a mouse model for arsenicinduced diabetes. Toxicol Appl Pharmacol. 2007;222(3):305-14. doi:10.1016/j.taap.2007.01.010.

81. Andrew AS, Jewell DA, Mason RA, Whitfield ML, Moore JH, Karagas MR. Drinking-water arsenic exposure modulates gene expression in human lymphocytes from a U.S. population. Environ Health Perspect. 2008;116(4):524-31. doi:10.1289/ehp. 10861.

82. Bourdonnay E, Morzadec C, Sparfel L, et al. Global effects of inorganic arsenic on gene expression profile in human macrophages. Mol Immunol. 2009;46(4):649-56. doi:10.1016/j. molimm.2008.08.268.

83. Xie Y, Liu J, Benbrahim-Tallaa L, et al. Aberrant DNA methylation and gene expression in livers of newborn mice transplacentally exposed to a hepatocarcinogenic dose of inorganic arsenic. Toxicology. 2007;236(1-2):7-15. doi:10.1016/j.tox.2007.03.021.

84. Smeester L, Rager JE, Bailey KA, et al. Epigenetic changes in individuals with arsenicosis. Chem Res Toxicol. 2011;24(2): 165-7. doi:10.1021/tx1004419.

85. Bailey KA, Wu MC, Ward WO, et al. Arsenic and the epigenome: interindividual differences in arsenic metabolism related to distinct patterns of DNA methylation. J Biochem Mol Toxicol. 2013;27(2):106-15. doi:10.1002/jbt.21462.

86. Rottiers V, Näär AM. MicroRNAs in metabolism and metabolic disorders. Nat Rev Mol Cell Biol. 2012;13(4):239-50. doi:10. 1038/nrm3313.

87. Pilsner JR, Liu X, Ahsan H, et al. Genomic methylation of peripheral blood leukocyte DNA: influences of arsenic and folate in Bangladeshi adults. Am J Clin Nutr. 2007;86(4):1179-86.

88. Pilsner JR, Liu X, Ahsan H, et al. Folate deficiency, hyperhomocysteinemia, low urinary creatinine, and hypomethylation of leukocyte DNA are risk factors for arsenic-induced skin lesions. Environ Health Perspect. 2009;117(2):254-60. doi:10.1289/ehp. 11872.

89. Ramirez CM, Goedeke L, Rotllan N, et al. MicroRNA 33 regulates glucose metabolism. Mol Cell Biol. 2013;33(15):2891-902. doi:10.1128/MCB.00016-13.

90. Lynn FC. Meta-regulation: microRNA regulation of glucose and lipid metabolism. Trends Endocrinol Metab. 2009;20(9):452-9. doi:10.1016/j.tem.2009.05.007.

91. Pullen TJ, da Silva XG, Kelsey G, Rutter GA. miR-29a and miR$29 \mathrm{~b}$ contribute to pancreatic beta-cell-specific silencing of monocarboxylate transporter 1 (Mct1). Mol Cell Biol. 2011;31(15):3182-94. doi:10.1128/MCB.01433-10.

92. Kriegel AJ, Liu Y, Fang Y, Ding X, Liang M. The miR-29 family: genomics, cell biology, and relevance to renal and cardiovascular injury. Physiol Genomics. 2012;44(4):237-44. doi:10.1152/ physiolgenomics.00141.2011.

93. Melkman-Zehavi T, Oren R, Kredo-Russo S, et al. miRNAs control insulin content in pancreatic $\beta$-cells via downregulation of transcriptional repressors. EMBO J. 2011;30(5):835-45. doi:10. 1038/emboj.2010.361.

94. Sturchio E, Colombo T, Boccia P, et al. Arsenic exposure triggers a shift in microRNA expression. Sci Total Environ. 2014;472(528):672-80. doi:10.1016/j.scitotenv.2013.11.092.

95. Meng XZ, Zheng TS, Chen X, et al. microRNA expression alteration after arsenic trioxide treatment in HepG-2 cells. J Gastroenterol Hepatol. 2011;26(1):186-93. doi:10.1111/j.14401746.2010.06317.x.

96. Ghaffari SH, Bashash D, Dizaji MZ, Ghavamzadeh A, Alimoghaddam K. Alteration in miRNA gene expression pattern in acute promyelocytic leukemia cell induced by arsenic trioxide: a possible mechanism to explain arsenic multi-target action. Tumor Biol. 2012;33(1):157-72. doi:10.1007/s13277-011-02591.

97. Marsit CJ, Eddy K, Kelsey KT. MicroRNA responses to cellular stress. Cancer Res. 2006;66(22):10843-8. doi:10.1158/00085472. CAN-06-1894.

98. Hou L, Wang D, Baccarelli A. Environmental chemicals and microRNAs. Mutat Res Fundam Mol Mech Mutagen. 2011;714(1-2):105-12. doi:10.1016/j.mrfmmm.2011.05.004.

99. Trajkovski M, Hausser J, Soutschek J, et al. MicroRNAs 103 and 107 regulate insulin sensitivity. Nature. 2011;474(7353):649-53. doi:10.1038/nature10112.

100. Kurtz CL, Fannin EE, Toth CL, et al. Inhibition of miR-29 has a significant lipid-lowering benefit through suppression of lipogenic programs in liver. Sci Rep. 2015;5:12911. doi:10.1038/srep12911.

101. Choi SE, Fu T, Seok S, et al. Elevated microRNA-34a in obesity reduces NAD+ levels and SIRT1 activity by directly targeting NAMPT. Aging Cell. 2013;12(6):1062-72. doi:10.1111/acel. 12135.

102. Fu T, Choi S-E, Kim D-H, et al. Aberrantly elevated microRNA34a in obesity attenuates hepatic responses to FGF19 by targeting a membrane coreceptor $\beta$-Klotho. Proc Natl Acad Sci U S A. 2012;109(40):16137-42. doi:10.1073/pnas.1205951109.

103. Frost RJA, Olson EN. Control of glucose homeostasis and insulin sensitivity by the let-7 family of microRNAs. Proc Natl Acad Sci U S A. 2011;108(52):21075-80. doi:10.1073/pnas.1118922109.

104. Liu X, Fortin K, Mourelatos Z. MicroRNAs: biogenesis and molecular functions. Brain Pathol. 2008;18(1):113-21. doi:10.1111/j. 1750-3639.2007.00121.x.

105. Salunkhe VA, Esguerra JLS, Ofori JK, et al. Modulation of microRNA-375 expression alters voltage-gated $\mathrm{Na}(+)$ channel properties and exocytosis in insulin-secreting cells. Acta Physiol (Oxf). 2015;213(4):882-92. doi:10.1111/apha.12460.

106. Tabet F, Vickers KC, Cuesta Torres LF, et al. HDL-transferred microRNA-223 regulates ICAM-1 expression in endothelial cells. Nat Commun. 2014;5:3292. doi:10.1038/ncomms4292.

107. Sollome J, Martin E, Sethupathy P, Fry RC. Environmental contaminants and microRNA regulation: transcription factors as regulators of toxicant-altered microRNA expression. Toxicol Appl Pharmacol. 2016. doi:10.1016/j.taap.2016.06.009.

108. Saini HK, Enright AJ, Griffiths-Jones S, et al. Annotation of mammalian primary microRNAs. BMC Genomics. 2008;9(1):564. doi: 10.1186/1471-2164-9-564.

109. Chen X, Ba Y, Ma L, et al. Characterization of microRNAs in serum: a novel class of biomarkers for diagnosis of cancer and 
other diseases. Cell Res. 2008;18(10):997-1006. doi:10.1038/cr. 2008.282.

110. Elamin BK, Callegari E, Gramantieri L, Sabbioni S, Negrini M. MicroRNA response to environmental mutagens in liver. Mutat Res Mol Mech Mutagen. 2011;717(1):67-76. doi:10.1016/j. mrfmmm.2011.03.015.

111. Hayes J, Peruzzi PP, Lawler S, et al. MicroRNAs in cancer: biomarkers, functions and therapy. Trends Mol Med. 2014;20(8): 460-9. doi:10.1016/j.molmed.2014.06.005.

112. Hulsmans M, Holvoet P. MicroRNAs as early biomarkers in obesity and related metabolic and cardiovascular diseases. Curr Pharm Des. 2013;19(32):5704-17.

113. Schembri F, Sridhar S, Perdomo C, et al. MicroRNAs as modulators of smoking-induced gene expression changes in human airway epithelium. Proc Natl Acad Sci U S A. 2009;106(7):2319-24. doi:10.1073/pnas.0806383106.

114. Vrijens K, Bollati V, Nawrot TS. MicroRNAs as potential signatures of environmental exposure or effect: a systematic review. Environ Health Perspect. 2015. doi:10.1289/ehp.1408459. This article provides a comprehensive look at miRNAs as potential biomarkers of exposure to toxicants, including arsenic.

115. Liu X-X, Li X-J, Zhang B, et al. MicroRNA-26b is underexpressed in human breast cancer and induces cell apoptosis by targeting SLC7A11. FEBS Lett. 2011;585(9):1363-7. doi:10.1016/j. febslet.2011.04.018.

116. Bollati V, Marinelli B, Apostoli P, et al. Exposure to metal-rich particulate matter modifies the expression of candidate microRNAs in peripheral blood leukocytes. Environ Health Perspect. 2010;118(6):763-8. doi:10.1289/ehp.0901300.

117. Sethupathy P. The promise and challenge of therapeutic microRNA silencing in diabetes and metabolic diseases. Curr Diab Rep. 2016;16(6):52. doi:10.1007/s11892-016-0745-3. This article presents a review of the most promising miRNA therapeutic targets in diabetes and related disorders. Several of the miRNAs discussed have been shown in independent studies to be responsive to arsenic exposure.

118. El Ouaamari A, Baroukh N, Martens GA, Lebrun P, Pipeleers D, van Obberghen E. miR-375 targets 3'-phosphoinositide-dependent protein kinase-1 and regulates glucose-induced biological responses in pancreatic beta-cells. Diabetes. 2008;57(10):2708-17. doi: $10.2337 / \mathrm{db} 07-1614$.

119. Poy MN, Eliasson L, Krutzfeldt J, et al. A pancreatic islet-specific microRNA regulates insulin secretion. Nature. 2004;432:226-30. doi:10.1038/nature03076.

120. Poy MN, Hausser J, Trajkovski M, et al. miR-375 maintains normal pancreatic alpha- and beta-cell mass. Proc Natl Acad Sci U S A. 2009;106(14):5813-8. doi:10.1073/pnas.0810550106.

121. Lovis P, Roggli E, Laybutt DR, et al. Alterations in microRNA expression contribute to fatty acid-induced pancreatic beta-cell dysfunction. Diabetes. 2008;57(10):2728-36. doi:10.2337/db071252.

122. Plaisance V, Abderrahmani A, Perret-Menoud V, Jacquemin P, Lemaigre F, Regazzi R. MicroRNA-9 controls the expression of granuphilin/Slp4 and the secretory response of insulin-producing cells. J Biol Chem. 2006;281(37):26932-42. doi:10.1074/jbc. M601225200.

123. Fred RG, Bang-Berthelsen CH, Mandrup-Poulsen T, Grunnet LG, Welsh N. High glucose suppresses human islet insulin biosynthesis by inducing miR-133a leading to decreased polypyrimidine tract binding protein-expression. PLoS One. 2010;5(5):e10843. doi:10.1371/journal.pone.0010843.

124. Tang X, Muniappan L, Tang G, Ozcan S. Identification of glucose-regulated miRNAs from pancreatic $\{$ beta $\}$ cells reveals a role for miR-30d in insulin transcription. RNA. 2009;15(2): 287-93. doi:10.1261/rna.1211209.

125. Dooley J, Garcia-Perez JE, Sreenivasan J, et al. The microRNA-29 family dictates the balance between homeostatic and pathological glucose handling in diabetes and obesity. Diabetes. 2016;65(1): 53-61. doi:10.2337/db15-0770.

126. Pullen TJ, da Silva XG, Kelsey G, Rutter GA. miR-29a and miR$29 \mathrm{~b}$ contribute to pancreatic-cell-specific silencing of monocarboxylate transporter 1 (Mct1). Mol Cell Biol. 2011;31(15):318294. doi:10.1128/MCB.01433-10.

127. Latreille M, Hausser J, Stützer I, et al. MicroRNA-7a regulates pancreatic beta cell function. J Clin Invest. 2014;124(6):272235. doi:10.1172/JCI73066.

128. Zhu Y, You W, Wang H, et al. MicroRNA-24/MODY gene regulatory pathway mediates pancreatic $\beta$-cell dysfunction. Diabetes. 2013;62(9):3194-206. doi:10.2337/db13-0151.

129. Fu T, Seok S, Choi S, et al. MicroRNA 34a inhibits beige and brown fat formation in obesity in part by suppressing adipocyte fibroblast growth factor 21 signaling and SIRT1 function. Mol Cell Biol. 2014;34(22):4130-42. doi:10.1128/MCB.00596-14.

130. Beezhold K, Liu J, Kan H, et al. miR-190-mediated downregulation of PHLPP contributes to arsenic-induced Akt activation and carcinogenesis. Toxicol Sci. 2011;123(2):411-20. doi:10.1093/ toxsci/kfr188.

131. Li X, Shi Y, Wei Y, Ma X, Li Y, Li R. Altered expression profiles of microRNAs upon arsenic exposure of human umbilical vein endothelial cells. Environ Toxicol Pharmacol. 2012;34(2):381-7. doi:10.1016/j.etap.2012.05.003.

132. Herbert KJ, Holloway A, Cook AL, Chin SP, Snow ET. Arsenic exposure disrupts epigenetic regulation of SIRT1 in human keratinocytes. Toxicol Appl Pharmacol. 2014;281(1):136-45. doi:10.1016/j.taap.2014.09.012.

133. Michailidi C, Hayashi M, Datta S, et al. Involvement of epigenetics and EMT-related miRNA in arsenic-induced neoplastic transformation and their potential clinical use. Cancer Prev Res (Phila). 2015;8(3):208-21. doi:10.1158/1940-6207.CAPR-140251.

134. Gonzalez H, Lema C, Kirken RA, Maldonado RA, VarelaRamirez A, Aguilera RJ. Arsenic-exposed keratinocytes exhibit differential microRNAs expression profile; potential implication of miR-21, miR-200a and miR-141 in melanoma pathway. Clin Cancer Drugs. 2015;2(2):138-47. doi:10.2174/ $2212697 X 02666150629174704$.

135. Cao Y, Yu S-L, Wang Y, Guo G-Y, Ding Q, An R-H. MicroRNAdependent regulation of PTEN after arsenic trioxide treatment in bladder cancer cell line T24. Tumor Biol. 2011;32(1):179-88. doi: 10.1007/s13277-010-0111-z.

136. Ren X, McHale CM, Skibola CF, Smith AH, Smith MT, Zhang L. An emerging role for epigenetic dysregulation in arsenic toxicity and carcinogenesis. Environ Health Perspect. 2011;119(1):11-9. doi:10.1289/ehp.1002114.

137. Kong APS, Xiao K, Choi KC, et al. Associations between microRNA (miR-21, 126, 155 and 221), albuminuria and heavy metals in Hong Kong Chinese adolescents. Clin Chim Acta. 2012;413(13):1053-7. doi:10.1016/j.cca.2012.02.014.

138. Rager J, Yosim A, Fry R. Prenatal exposure to arsenic and cadmium impacts infectious disease-related genes within the glucocorticoid receptor signal transduction pathway. Int J Mol Sci. 2014;15(12):22374-91. doi:10.3390/ijms151222374.

139. Pritchard CC, Cheng HH, Tewari M. MicroRNA profiling: approaches and considerations. Nat Rev Genet. 2012;13(5):35869. doi:10.1038/nrg3198. 